Shady Practices 
California Studies in Critical Human Geography Editorial Board

Professor Michael Watts, University of California, Berkeley

Professor Allan Pred, University of California, Berkeley

Professor Richard Walker, University of California, Berkeley

Professor Gillian Hart, University of California, Berkeley

Professor AnnaLee Saxenian, University of California, Berkeley

Professor Mary Beth Pudup, University of California, Santa Cruz

1. Changing Fortunes: Biodiversity and Peasant Livelihood in the Peruvian Andes, by Karl S. Zimmerer

2. Making the Invisible Visible: A Multicultural Planning History, edited by Leonie Sandercock

3. Imperial San Francisco: Urban Power, Earthly Rum, by Gray Brechin

4. Imposing Wilderness: Struggles over Livelihood and Nature Preservation in Africa, by Roderick P. Neumann

5. Shady Practices: Agroforestry and Gender Politics in The Gambia, by Richard A. Schroeder

6. On Vacation, by Orvar Löfgren 


\section{Shady Practices}

Agroforestry and Gender Politics in The Gambia

Richard A. Schroeder

UNIVERSITY OF CALIFORNIA PRESS

Berkeley . Los Angeles . London 


\section{Library of Congress Cataloging-in-Publication Data}

Schroeder, Richard A.

Shady practices : agroforestry and gender politics in the Gambia/Richard A. Schroeder.

p. cm. - (California studies in critical human geography ; 5)

Includes bibliographical references and index.

ISBN 0-520-21687-3 (alk, paper)

I. Mandingo (African people)-Agriculture. 2. Mandingo (African people)-Social conditions. 3. Women, Mandingo--Economic conditions. 4. Division of labor-Gambia-Alkalikunda. 5. Patriarchy-Gambia-Alkalikunda. 6. Agroforestry-Gambia-Alkalikunda. 7. Sex role-Political aspects-GambiaAlkalikunda. 8. Forest ecology-Gambia-Alkalikunda. 9. Alkalikunda (Gambia)---Social life and customs. I. Title. II. Series.

DT509.45.M34\$37 1999

$338 . I^{\prime} 09665 \mathrm{I}-\mathrm{dc} 2 \mathrm{I}$

$99-18198$

CIP

Manufactured in the United States of America

The paper used in this publication meets the minimum requirements of ANSI / NISO Z39.48-1992

(R 1997) (Permanence of Paper).

This book is a printondemand wolume. $l l$ is manufactured using toner in place of ink. Type and images may be less sharp than the same material secen in traditionally printed University of California Press edivions.

Portions of this text have been previously published. Chapter 3 first appeared as "Gone to their second husbands': Marital metaphors and conjugal contracts in The Gambia's female garden sector," Canadian Joumal of African Studies 30, I (1996): 69-87, and has been reprinted with permission.

Excerpts of the following articles have also been reprinted with permission: "Shady practice: Gender and the political ecology of resource stabilization in Gambian garden / orchards," Economic Geography 69, 4 (I993): 349-365; "Contradictions along the commodity road to environmental stabilization: Foresting Gambian gardens," Antipode 27, 4 (r995):325-342; and "Re-claiming' land in The Gambia: Gendered property rights and environmental intervention," Annals of the Association of American Geographers 87, 3 (1997): $487-508$.

Tables 9 and 10 originally appeared in Susan B. Roberts, A. A. Paul, T. J. Cole, and R. G. Whitehead "Seasonal changes in activity, birth weight and lactational performance in rural Gambian women," Transactions of the Royal Society of Tropical Medicine and Hygiene 76, 5 (1982): $668-678$, and were reprinted in H. R. Barrett and A. W. Browne "Time for development? The case of women's horticultural schemes in rural Gambia," Scottish Geographical Magazine Io5, I (r989): 4-II. Adapted versions of the originals are reprinted here with permission.

Table 12 originally appeared in H. R. Barrett and A. W. Browne "Time for development? The case of women's horticultural schemes in rural Gambia," Scottish Geographical Magazine 105, I (1989): 4-II, and is reprinted with permission.

All photographs in this book are by the author. 
This book is dedicated to the memory

of my mother,

Iola (Odie) Belle Root Schroeder Borchert (I929-I978)

and my grandmother,

Esther Gertrude Margaret Gehring Root (I900-I996) 
This page intentionally left blank 